\title{
ARBUSCULAR MYCORRHIZAL FUNGI (GLOMEROMYCOTA) ASSOCIATED WITH ROOTS OF AMMOPHILA ARENARIA GROWING IN MARITIME DUNES OF BORNHOLM (DENMARK)
}

\author{
JANUSZ BŁASZKOWSKI, BEATA CZERNIAWSKA \\ Department of Plant Protection, West Pomeranian University of Technology \\ Słowackiego 17, 71-434 Szczecin, Poland \\ janusz.blaszkowski@zut.edu.pl
}

(Received: March 11, 2010. Accepted: January 5, 2011)

\begin{abstract}
155 rhizosphere soil and root mixtures were collected from under Ammophila arenaria colonizing maritime dunes of the island Bornholm (Denmark) to determine arbuscular mycorrhizal fungi (AMF) of the phylum Glomeromycota co-existing with this plant. In the laboratory, each mixture was divided into two parts. One part was used to establish a pot culture with Plantago lanceolata as the host plant to initiate sporulation of fungi that had not produced spores in field conditions. In the second part, the numerical and species composition of the spore populations of AMF sporulating in the field was determined. Spores of AMF were found in 70 fieldcollected samples and 134 trap cultures. They represented 26 species and six undescribed morphotypes in six genera of the Glomeromycota. Of them, 20 species and three morphotypes in five genera occurred in the field, and 16 species and three morphotypes in five genera were found in trap cultures. The fungi most frequently revealed were members of the genus Glomus; a total of 17 species and six morphotypes of this genus were recognized. Considering the occurrence of spores in both field samples and trap cultures, the fungi most frequently co-occurring with roots of $A$. arenaria growing in the dunes of Bornholm were G. irregulare (present in $73.6 \%$ of samples), followed by Scutellospora dipurpurescens (19.4\%) and Archaeospora trappei (10.3\%). However, Glomus irregulare mainly sporulated in trap cultures; spores of this fungus were found in only $0.6 \%$ of field samples. Other relatively frequently found species were G. aggregatum (9.0\%), G. eburneum (7.1\%), Paraglomus laccatum (5.2\%), and S. armeniaca (6.5\%). The species most abundantly sporulating in the field were G. aggregatum (produced $28.36 \%$ of all spores isolated), G. badium (11.00\%), and S. dipurpurescens $(21.55 \%)$.
\end{abstract}

KEY WORDS: arbuscular mycorrhizal fungi, Bornholm, distribution, Glomeromycota, maritime sand dunes.

\section{INTRODUCTION}

Arbuscular mycorrhizal fungi (AMF) occur commonly in the world and associate with $70-90 \%$ of vascular land plants (Smith and Read 2008).

Habitats especially favoring AMF are maritime sand dunes (Koske 1987; Dalpé 1989; Tadych and Błaszkowski 2000a), mainly because of their low nutrient content and organic components (Koske 1988; Nicolson and Johnston 1979). The association of AMF with maritime dune plants may be of considerable ecological significance for their establishment and growth, because these fungi enhance plant nutrient uptake, increase plant tolerance to drought and salt stress, and protect against soil pathogens (Koske et al. 2004). At least 32 newly described species of AMF have originally been associated with roots of dune plants and many others have occurred in maritime dunes (Sridhar and Beena 2001; Błaszkowski 2003).
At present, AMF are placed in the phylum Glomeromycota C. Walker et Schuessler, comprising four orders, ten families, and fourteen genera (Schüßler et al. 2001; Błaszkowski 2003; Oehl and Sieverding 2004; Sieverding and Oehl 2006; Walker and Schüßler 2004; Walker et al. 2007a, b; Palenzuela et al. 2008; Walker 2008). The most numerous group of fungi in the Glomeromycota is the genus Glomus Tul. et C. Tul., including ca. $53 \%$ of all AMF described to date, i.e., ca. 210 species (Błaszkowski 2003). However, Morton (2000) hypothesized, when 154 species were known in the literature, that the number of existing species of AMF may be at least 2-fold higher. The hypothesis agrees with the results of recent molecular investigations of diversity of AMF indicating that many revealed sequence types cannot be assigned to named fungi (e.g. Hijri et al. 2006).

The reasons of omissions of these unknown species functioning in different ecosystems around the world may 
be (1) lack or rare sampling of AMF in most regions of the Earth, (2) the few specialized and experienced mycologists dealing with morphology of members of the Glomeromycota, and (3) seasonal, rare or no sporulation of many AMF in the field conditions (Gemma et al. 1989; Stürmer and Bellei 1994; Stutz and Morton 1996).

An effective method forcing production of spores of AMF hidden inside roots of their host plants is cultivation of field-collected mixtures of rhizosphere soils and root fragments of these plants in successive (Stutz and Morton 1996) or long-term (Oehl et al. 2004) pot trap cultures.

Bornholm is one of the 443 islands and the easternmost located administrative district of Denmark (officially the Kingdom of Denmark) of the geographical coordinates of $55^{\circ} 5^{\prime} \mathrm{N}$ and $14^{\circ} 56^{\prime} \mathrm{E}$. It occupies an area of ca. $600 \mathrm{~km}^{2}$ and the length of its coastal line is ca. $141 \mathrm{~km}$. Because of the favourable climate, the plants growing on the island are, e.g. orchids, anemone, and many species of the Mediterranean Sea region. Therefore, Bornholm is named a green island, and its flag is a modified flag of Denmark, in which the white cross is replaced with a green one. Lawesson and Skov (2002) found that the highest plant diversity in Denmark occurs on its major islands, including Bornholm.

The eastern, northern, and western coasts of Bornholm generally are rocky with only small sandy areas, whereas the southern coast is represented by extensive and wide (up to $1 \mathrm{~km}$ ) beaches and mobile dunes colonized mainly by Ammophila arenaria (L.) Link.

In the literature, there is only one report of fungi found in Bornholm. It regards the newly described species, Glomus irregulare Błaszk. et. al., and co-occurring other AMF (Błaszkowski et al. 2008a).

The aim of this paper is to show the results of investigations of the occurrence of AMF associated with roots of Am. arenaria colonizing maritime dunes of Bornholm. The presence of AMF was determined based on both spores isolated from field-collected mixtures of the rhizosphere soil and root fragments of Am. arenaria and pot trap cultures established from part of each field mixture. The spore populations of AMF revealed were analyzed using different statistical methods. Additionally, the known distribution of the revealed species and undescribed morphotypes in maritime dunes of other regions of the world is presented and discussed.

\section{MATERIALS AND METHODS}

\section{Study sites}

The study sites were maritime sand dunes located along the bank of the Baltic Sea surrounding the Bornholm island belonging to Denmark. Mixtures of rhizosphere soils and root fragments were collected from eight dune sites located

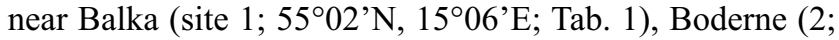
$\left.55^{\circ} 01^{\prime} \mathrm{N}, 14^{\circ} 54^{\prime} \mathrm{E}\right)$, Dueodde $\left(3,6\right.$, and $7 ; 54^{\circ} 59^{\prime} \mathrm{N}$, $\left.15^{\circ} 04^{\prime} \mathrm{E}\right)$, Hasle ( 4 and $8 ; 55^{\circ} 10^{\prime} \mathrm{N}, 14^{\circ} 42^{\prime} \mathrm{E}$ ), and Snogebæk $\left(5 ; 55^{\circ} 01^{\prime} \mathrm{N}, 15^{\circ} 07^{\prime} \mathrm{E}\right)$. Most samples were taken from sites $2,3,6$, and 7 .

Based on data from 1961-1990 (www.dmi.dk/dmi/index/ danmark/klimanormaler.htm), the mean annual sum of rainfall in Bornholm is $604 \mathrm{~mm}$; it is highest in November $(76 \mathrm{~mm})$, and lowest in February $(32 \mathrm{~mm})$. The mean annual temperature is $7.9^{\circ} \mathrm{C}$; it is highest in August $\left(16.7^{\circ} \mathrm{C}\right)$, and lowest in January $\left(0.1^{\circ} \mathrm{C}\right)$.

\section{Soil chemical analyses}

The contents of total $\mathrm{N}$ and organic $\mathrm{C}$ were determined according to Kjeldahl, $\mathrm{P}$ and $\mathrm{K}$ after Egner-Riehm, and $\mathrm{Mg}$ after Schachtschabe (Ostrowska et al. 1991).

\section{Collection of soil and root samples, establishment of trap and single-species cultures, and extraction of spores of $A M F$}

155 rhizosphere soils and roots of sampled plants were collected on 2-3 October 2004 from a depth of 5-30 cm using a small garden shovel. About $100-200 \mathrm{~cm}^{3}$ samples were placed in plastic bags. After their transfer to a laboratory in Poland, they were first stored at $4^{\circ} \mathrm{C}$ for ca. one month and then used to establish trap cultures. Trap cultures were established to initiate sporulation of AM fungal species rarely sporulating in the field and species that did not produce spores at the time of collection of the field samples. The growing substrate of the trap cultures was the field-collected material mixed with an autoclaved coarse-grained sand coming from maritime dunes adjacent to Świnoujście ( $\mathrm{pH} 6.7 ; 12$ and $26 \mathrm{mg} \mathrm{L}^{-1} \mathrm{P}$ and $\mathrm{K}$, respectively; Błaszkowski 1995). The mixtures were placed into $9 \times 12.5-\mathrm{cm}$ plastic pots $\left(500 \mathrm{~cm}^{3}\right)$ and densely seeded with Plantago lanceolata L. Plants were grown in a greenhouse at $15-30^{\circ} \mathrm{C}$ with supplemental 8-16-h lighting provided by one SON-T AGRO sodium lamp (Philips Lighting Poland S.A.) placed $1 \mathrm{~m}$ above pots. The maximum light intensity was $180 \mu \mathrm{E} \mathrm{m} \mathrm{m}^{-2} \mathrm{~s}^{-1}$ at pot level. Plants were watered 2-3 times a week. No fertilizer was applied during the growing period. Trap cultures were for the first time harvested four months after plant emergence and then every ca. 6 months until 2008. After each harvest, the cultures were reseeded with $P$. lanceolata. Spores were extracted by wet sieving and decanting (Gerdemann and Nicolson 1963).

Spores of identical morphological characters were used to establish single-species cultures. Single-species cultures were established and grown as given in Błaszkowski et al. (2006), with two exceptions. First, instead of marine sand their growing medium was an autoclaved commercially available coarse-grained sand (grains 1.0-10.0 mm diam. $80.50 \%$; grains $0.1-1.0 \mathrm{~mm}$ diam $-17.28 \%$; grains $<0.1$ $\mathrm{mm}$ diam. $-2.22 \%)$ mixed $(5: 1, \mathrm{v} / \mathrm{v})$ with clinopthilolite (Zeocem, Bystré, Slovakia) of grains 2.5-5 mm. Clinopthilolite is a crystaline hydrated alumosilicate of alkali metals and alkaline earth metals having, e.g., a high ion exchange capability and selectivity, as well as a reversible hydration and dehydration. $\mathrm{pH}$ of the sand-clinopthilolite mixture was 7.3. Second, the cultures were kept in transparent plastic bags, $15 \mathrm{~cm}$ wide and $22 \mathrm{~cm}$ high as suggested by Walker and Vestberg (1994), rather than open pot cultures (Gilmore 1968). To prevent contamination of the cultures with other AMF but still to allow exchange of gases, we left an opening, about $1 \mathrm{~cm}$ wide, in the centre of the upper part of each bag, while the edges on both sides were closed with small plastic clips. The cultures were watered with tap water once a week, harvested after five months when spores were extracted for study. To reveal mycorrhizal root structures, root fragments located ca. 1-5 $\mathrm{cm}$ below the upper level of the growing medium were cut 
off with a scalpel. The host plant of single-species cultures was also P. lanceolata.

\section{Microscopy survey}

Morphological properties of spores and their wall structures were determined based on observation of at least 100 spores mounted in polyvinyl alcohol/lactic acid/ glycerol (PVLG; Omar et al. 1979) and a mixture of PVLG and Melzer's reagent $(1: 1, \mathrm{v} / \mathrm{v})$. Spores were crushed to varying degrees by applying pressure to the cover slip and then stored at $65^{\circ} \mathrm{C}$ for $24 \mathrm{~h}$ to clear their contents from oil droplets. These were examined under an Olympus BX 50 compound microscope equipped with Nomarski differential interference contrast optics. Microphotographs were recorded on a Sony $3 \mathrm{CDD}$ color video camera coupled to the microscope.

Terminology of spore structure is that suggested by Stürmer and Morton (1997) and Walker (1983). Spore colour was examined under a dissecting microscope on fresh specimens immersed in water. Nomenclature of fungi and plants is that of Walker and Trappe (1993) and Mirek et al. (info.botany.pl/czek/check.htm), respectively. The authors of the fungal names are those presented at the URL web page http://www.indexfungorum.org/AuthorsOfFungal Names.htm. Specimens were mounted in PVLG on slides and deposited in the Department of Plant Protection, West Pomeranian University of Technology, Szczecin Poland.

Colour microphotographs of spores and mycorrhizae of the formally described species can be viewed at the URL http://www.agro.ar.szczecin.pl/ jblaszkowski/.

\section{Statistical analysis}

Differences in the structure of arbuscular fungal communities were investigated by determining the frequency of occurrence of species, spore abundance and species richness, and by calculating dominance coefficients (Górny and Gruma 1981) and total spore volumes. Spore abundance, coefficients of dominance, and the total volume of spores of each species were determined based on spores isolated only from field-collected samples. Frequency of occurrence and species richness were calculated based on spores isolated from both field-collected samples and trap cultures. Frequency of occurrence was calculated by determining the percentage of field-collected samples and trap cultures from which spores of a particular species were recovered. Spore abundance and species richness were defined by determining the number of spores and species, respectively, occurring in $100 \mathrm{~g}$ dry soil. Dominance coefficient expresses the proportion of the number of spores of a particular species in all spores of AMF recovered. The total spore volume was calculated by multiplying the total number of spores of a given species by the average volume of a spore of this species. The average volume of a spore was calculated from its average diameter and equation of a sphere.

\section{RESULTS AND DISCUSSION}

\section{General data}

The soil chemical properties of the sites sampled are shown in Table 1. $\mathrm{pH}$ in $1 \mathrm{M} \mathrm{KCl}$ ranged from slightly acid to neutral. The contents of total $\mathrm{N}$ was very low, and organic $\mathrm{C}$ low. The concentration of available $\mathrm{Mg}$ was medium. The availability of $\mathrm{K}$ and $\mathrm{P}$ was very low to low.

Spores of AMF were found in only 70 of the 155 fieldcollected samples, but they occurred in 134 trap cultures with each field sample, i.e., in $87 \%$ of all the trap cultures established.

The spores isolated from both the field samples and trap cultures represented 26 species and 6 undescribed morphotypes in 6 genera of the Glomeromycota (Table 2).

In the field samples, 20 species and three undescribed morphotypes in five genera were found, and 16 species and three morphotypes in five genera were isolated from trap cultures.

Ten species and three undescribed morphotypes in four genera were found only in the field samples, and six species and three morphotypes in two genera were revealed only in trap cultures. Ten species in four genera sporulated in both the field and trap cultures.

The low percent of the field-collected root-soil mixtures with the exceptionally low numbers of spores, the disclosure in trap cultures of six species and three undescribed morphotypes not sporulating in the field, and the frequent occurrence of spores of species found in this study in the field of other dune sites of Poland and the world indicate that the Bornholm dunes do not favour sporulation of AMF.

The high predominance of members of the genus Glomus in the communities of AMF of dunes of Bornholm agrees with the species composition of these fungi recovered from dunes of the Baltic Sea (Błaszkowski 1993a, b), the Hel Peninsula (Błaszkowski 1994a), Italy (Giovannetti and Nicolson 1983; Puppi and Riess 1987), Scotland (Nicolson and Johnston 1979), Madras, India (Mohankumar et al. 1988), Canada (Dalpé 1989), Florida (Sylvia 1986; Sylvia

TABLE 1. Chemical properties of soils of the eight examined maritime sand dune sites of Bornholm.

\begin{tabular}{|c|c|c|c|c|c|c|}
\hline \multirow[t]{2}{*}{ No. of site* } & \multirow[t]{2}{*}{$\mathrm{pH}$ in $1 \mathrm{M} \mathrm{KCl}$} & \multicolumn{2}{|c|}{ Contents in } & \multicolumn{3}{|c|}{ Available forms in $\mathrm{mg} / 100 \mathrm{~g}$ of soil } \\
\hline & & Total N & org. $\mathrm{C}$ & $\mathrm{Mg}$ & $\mathrm{K}$ & $\mathrm{P}$ \\
\hline 1 & 6.50 & 0.18 & 1.77 & 3.17 & 2.16 & 0.84 \\
\hline 2 & 6.70 & 0.19 & 1.86 & 3.47 & 2.66 & 1.06 \\
\hline 3 & 6.75 & 0.22 & 2.14 & 3.40 & 2.57 & 1.67 \\
\hline 4 & 6.40 & 0.25 & 2.41 & 3.14 & 2.60 & 2.55 \\
\hline 5 & 6.55 & 0.23 & 2.25 & 2.95 & 2.74 & 2.02 \\
\hline 6 & 6.61 & 0.24 & 2.32 & 2.84 & 2.99 & 1.10 \\
\hline 7 & 6.59 & 0.20 & 1.95 & 3.24 & 2.57 & 1.27 \\
\hline 8 & 6.62 & 0.22 & 2.15 & 3.02 & 2.32 & 2.30 \\
\hline
\end{tabular}

* see Materials and methods 
TABLE 2. Arbuscular mycorrhizal fungi associated with roots of Ammophila arenaria colonizing maritime dunes of Bornholm.

\begin{tabular}{|c|c|c|c|c|}
\hline \multirow[t]{2}{*}{ Fungi } & \multicolumn{2}{|c|}{$\begin{array}{c}\text { Frequency } \\
\text { of occurrence }(\%)\end{array}$} & \multirow[t]{2}{*}{$\begin{array}{c}\text { Dominance } \\
(\%)\end{array}$} & \multirow{2}{*}{$\begin{array}{c}\text { Total spore } \\
\text { volume } \\
\mu \mathrm{m}^{3} \times 10^{6}\end{array}$} \\
\hline & Field soils & $\begin{array}{c}\text { Trap } \\
\text { cultures }\end{array}$ & & \\
\hline Acaulospora lacunosa J.B. Morton & 0.6 & - & 0.73 & 44.56 \\
\hline Acaulospora mellea Spain et N.C. Schenck & 4.5 & 0.6 & 7.27 & 522.40 \\
\hline Ambispora gerdemannii (S.L. Rose, B.A. Daniels et Trappe) C. Walker, Vestberg et Schuessler & 0.6 & - & 0.27 & 77.54 \\
\hline Archaeospora trappei (Ames et Linderman) Morton et Redecker & 0.6 & 10.3 & 0.003 & 2.10 \\
\hline Glomus aggregatum Schenck et Smith emend. Koske & 7.1 & 9.0 & 28.36 & 829.92 \\
\hline Glomus badium Oehl, Redecker et Sieverd. & 0.6 & - & 11.0 & 84.70 \\
\hline Glomus claroideum Schenck et Smith & 0.6 & - & 0.09 & 10.30 \\
\hline Glomus constrictum Trappe & 0.6 & 2.6 & 0.09 & 17.15 \\
\hline Glomus drummondii Błaszk. et Renker & - & 1.3 & - & - \\
\hline Glomus eburneum L.J. Kenn., J.C. Stutz et J.B. Morton & - & 7.1 & - & - \\
\hline Glomus etunicatum W.N. Becker et Gerd. & 0.6 & - & 0.18 & 7.18 \\
\hline Glomus fasciculatum (Thaxter) Gerd. et Trappe emend. Walker et Koske & 0.6 & 1.9 & 10.0 & 552.90 \\
\hline Glomus geosporum (T.H. Nicolson et Gerd.) C. Walker & 1.3 & - & 0.91 & 224.30 \\
\hline Glomus gibbosum Błaszk. & 1.3 & - & 1.36 & 70.65 \\
\hline Glomus intraradices N.C. Schenck et G.S. Sm. & 0.6 & 0.6 & 0.91 & 32.60 \\
\hline Glomus irregulare Błaszk., Wubet, Renker et Buscot & 0.6 & 73.6 & 0.18 & 4.78 \\
\hline Glomus lamellosum Dalpé, Koske et Tews & - & 0.6 & - & - \\
\hline Glomus mosseae (T.H. Nicolson et Gerd.) Gerd. et Trappe & 0.6 & 0.6 & 0.18 & 53.02 \\
\hline Glomus pustulatum Koske, Friese, C. Walker et Dalpé & 3.9 & 2.6 & 4.91 & 226.26 \\
\hline Glomus versiforme (P. Karsten) S.M. Berch & - & 1.9 & - & - \\
\hline Glomus walkeri Błaszk. et Renker & - & 0.6 & 0.18 & - \\
\hline Glomus 130 & 0.6 & - & 1.45 & 2.71 \\
\hline Glomus 149 & - & 3.2 & - & - \\
\hline Glomus 178 & - & 7.1 & - & - \\
\hline Glomus 194 & 0.6 & - & 0.82 & 1.12 \\
\hline Glomus 202 & - & 0.6 & - & - \\
\hline Glomus 206 & 0.6 & - & 0.27 & 0.54 \\
\hline Paraglomus laccatum (Błaszk.) Renker, Błaszk. et Buscot & - & 5.2 & - & - \\
\hline Scutellospora armeniaca Błaszk. & 6.5 & - & 8.64 & 882.56 \\
\hline Scutellospora dipurpurescens Morton et Koske & 19.4 & 5.8 & 21.55 & 13006.51 \\
\hline Scutellospora pellucida (Nicol. et Schenck) Walker et Sanders & 1.3 & - & 0.18 & 62.08 \\
\hline Scutellospora persica (Koske et C. Walker) C. Walker et F.E. Sanders & 0.6 & - & 0.009 & 137.19 \\
\hline
\end{tabular}

and Will 1988), Wisconsin (Koske and Tews 1987), San Miguel, California (Koske and Halvorson 1989; Koske, pers. comm.), and Hawaii (Koske 1988; Koske and Gemma 1996). In contrast, maritime dunes of Massachussets (Bergen and Koske 1984; Gemma and Koske 1988; Gemma et al. 1989), Rhode Island (Friese and Koske 1991; Koske and Halvorson 1981), the Atlantic coast from New Jersey to Virginia (Koske 1987), northern California (Rose 1988), and New South Wales, Australia (Koske 1975) were dominated by Gigaspora and Scutellospora spores.

The high predominance and diversity of members of the genus Glomus in dunes of Bornholm supports earlier reports of a good adaptation of these fungi to a wide range of physical and chemical soil conditions (Anderson et al. 1984; Grey 1991; Haas and Menge 1990; Porter et al. 1987). Daniels and Trappe (1980) found that the optimal temperature for germination of spores of Glomus spp. was $14-22^{\circ} \mathrm{C}$, i.e., a temperature range of a vegetative period of Bornholm (www.dmi.dk/dmi/index/danmark/klimanormaler.htm). In contrast, species of Gigaspora and Scutellospora prefer warmer soils (Koske 1981; Schenck et al. 1975). Koske (1987) proved statistically that temperature was the main abiotic factor determining the structure of AMF community in dunes extending from New Jersey to Virginia. Acaulospora and Archaeospora spp. rarely dominate in AMF communities (Błaszkowski 1991, 1993a, b, 1994a; Gerdemann and Trappe 1974).
The main reasons of the lack of sporulation in trap cultures of nine species and three morphotypes revealed only in the field-collected samples probably were (1) expulsion or suppression of these fungi by species more competitive or faster adjusting to the conditions of trap cultures and (2) incompatibility of the above- and underground conditions and the plant host of these cultures with the ecological requirements of these fungal species. Then, the lack of findings of six species and three morphotypes in the field samples, which later produced spores in trap cultures, may have resulted from either the lack of sporulation of these species at the time of sampling of the field root-soil mixtures or too low level of colonization of roots of $A$. arenaria by these fungi. Many species of AMF sporulate seasonally or not at all in the field (Gemma and Koske 1988; Gemma et al. 1989) and the beginning of sporulation requires attaining a minimum threshold level of root colonization, which is regulated by the fungal genotype alone or in combination with host factors (Franke and Morton 1994; Gazey et al. 1992; Stutz and Morton 1996).

\section{Frequency of occurrence}

The fungi most frequently identified were members of the genus Glomus (Table 2). A total of 17 species and six morphotypes of Glomus were revealed. Other fungi relatively frequently occurring in the dunes of Bornholm were Scutellospora species: four species were recognized. 
Taking into account the frequency of occurrence of the AMF identified in both the field soils and trap cultures, the fungus most frequently occurring in dunes of Bornholm was $G$. irregulare, which sporulated very infrequently in the field, but was the most frequently found fungus in trap cultures (Table 2). Another frequently occurring AMF was $S$. dipurpurescens, which, however, markedly more frequently sporulated in the field conditions. Additionally, relatively frequently revealed fungi also were Ar. trappei, G. eburneum, $S$. armeniaca, and P. laccatum. Of them, $S$. armeniaca was found only in field-collected samples, and spores of $G$. eburneum and P. laccatum were revealed only in trap cultures. Archaeospora trappei spores also were extracted mainly from trap cultures.

\section{Spore abundance}

The overall average ( \pm S.D.) spore abundance of AMF in the field-collected soil-root mixtures was $7.36 \pm 22.10$ and ranged from 0 to 153 spores in $100 \mathrm{~g}$ dry soil.

Such a low spore abundance of AMF has been recorded only in dunes of Cape Cod, Massachusetts (0.2-16.2 spores in $100 \mathrm{~g}$ dry soil; Bergen and Koske 1984), Santa Catarina, Brasil (0-69; Stürmer and Bellei 1994), and Pakistan (1-29; Khan 1974).

In Poland, the average abundances of spores in $100 \mathrm{~g}$ dry soil of the Baltic Sea coastal dunes located in the former Gdańsk and Szczecin districts were 96.7 and 72.0, respectively (Błaszkowski 1993b), the Hel Peninsula 99.8 (Błaszkowski 1994a), and the Słowiński National Park (SPN) 75.9 (Tadych and Błaszkowski 2000a).

In maritime dunes of other regions of the world, the spore abundance of AMF has also generally been markedly higher than that in dunes of Bornholm: Florida (0-677; Sylvia 1986; Sylvia and Will 1988), Lake Huron (0-632; Koske et al. 1975), Rhode Island (101-336; Koske and Halvorson 1981), Italy (0-250; Puppi and Riess 1987), and New South Wales (0-110; Koske 1975).

\section{Species richness}

Taking into account the spores isolated from both the field-collected samples and trap cultures, the overall average $( \pm$ S.D. $)$ species richness of AMF in dunes of Bornholm was $1.83 \pm 1.26$ and ranged from 0 to 6 .

Similar overall average species richness data were recorded from dunes of the Cape Cod, Massachusetts (av. 1.7; Bergen and Koske 1984), SNP (av. 2.4) and the Szczecin coast (av. 2.2) examined by Błaszkowski (1993b), New South Wales (av. 1.5-2.4; Koske 1975), and Hawaii (av. 2.0 and 2.4; Koske 1988, Koske and Gemma 1996, respectively). Higher richness values were noted in dunes of the Gdańsk coast (av. 3.6; Błaszkowski 1993b), the Hel Peninsula (av. 3.9; Błaszkowski 1994a), Rhode Island (av. 3.1; Koske and Halvorson 1981), New Jersey to Virginia (av. 4.9; Koske 1987), and Santa Catarina, Brazil (av. 5.9; Stürmer and Bellei 1994).

\section{Dominance}

The eudominants (of a coefficient of dominance of $\mathrm{D}>10.0 \%$ ) of dune soils of Bornholm were G. aggregatum, $S$. dipurpurescens, and G. badium (Table 2). The dominants $(\mathrm{D}=5.1-10.0 \%)$ were $G$. fasciculatum, $S$. armeniaca, and $A$. mellea.
Glomus aggregatum has been the only AMF found in maritime sand dunes of Scotland (Nicolson and Johnston 1979; Koske pers. comm.). It has also dominated in maritime sand dunes and shores of Quebec, New Brunswick and Nova Scotia, Canada (Dalpé 1989).

Scutellospora dipurpurescens has dominated in dunes of SNP (Błaszkowski 1993b; Tadych and Błaszkowski 2000a)

In contrast, the dunes of the Szczecin coast have been dominated by $G$. corymbiforme, $G$. pustulatum and $S$. dipurpurescens, and those of the Gdańsk coast by $G$. constrictum and G. ? heterosporum Smith et Schenck (Błaszkowski 1993b). Glomus microcarpum, S. dipurpurescens and $G$. constrictum have predominated in the Hel Peninsula dunes (Błaszkowski 1994a). The dominant AMF of Italian dunes have been $G$. mosseae (Nicol. et Gerd.) Gerd. et Trappe, S. calospora (Nicol. et Gerd.) Walker et Sanders, G. macrocarpum and G. microcarpum (Giovannetti and Nicolson 1983; Puppi and Riess 1987). In the Lake Huron dunes, Canada, the dominating AMF have been $G$. caledonium (Nicol. et Gerd.) Trappe et Gerd. and a species forming yellow brown spores (Koske et al. 1975). The populations of AMF of dunes of the eastern coast of the U.S.A. have been dominated by A. scrobiculata Trappe, $G$. gigantea, $G$. deserticola, G. fasciculatum, and Scutellospora weresubiae Koske et Walker (Bergen and Koske 1984; Koske 1987; Koske and Halvorson 1981; Sylvia 1986; Sylvia and Will 1988). The most abundantly sporulating fungus in the Wisconsin Great Lake dunes has been G. etunicatum (Koske and Tews 1987). Scutellospora coralloidea (Trappe, Gerd. et Ho) Walker et Sanders, $S$. heterogama (Nicol. et Gerd.) Walker et Sanders and $S$. calospora (Nicol. et Gerd.) Walker et Sanders have predominated in the Lanphere-Christensen sand dunes of the Pacific Coastline (Rose 1988). Scutellospora hawaiiensis Koske et Gemma, G. microaggregatum Koske, Gemma et Olexia, G. sinuosum (Gerd. et Bashi) Almeida et Schenck, Glomus 807, G. intraradices and Diversispora spurca (C.M. Pfeiff., C. Walker et Bloss) C. Walker et Schuessler have belonged to the most abundant species in the root zone of plants of Hawaiian dunes (Koske 1988; Koske and Gemma 1996). In dunes of San Miguel Island, the species most frequently occurring have been $G$. etunicatum, G. pansihalos, and G. trimurales (Koske, pers. comm.). Most spores isolated from sand dunes of Santa Catarina, Brazil, have belonged to A scrobiculata (Stürmer and Bellei 1994). The dune plants of the west coast of India have most frequently hosted G. albidum, G. clarum, G. fasciculatum (Kulkarni et al. 1997), Gigaspora margarita, G. sinuosum, S. calospora, and S. pellucida (D'Cunha and Sridhar 2009). The coastal sand dunes of New South Wales have been predominated by $A$. scrobiculata and a red-brown-spored species (Koske 1975).

\section{Total spore volume}

The species of AMF of dunes of Bornholm forming spores of the markedly greatest total spore volume was $S$. dipurpurescens (Table 2). Other species yielding high spore volumes were $S$. armeniaca, $G$. aggregatum, $G$. fasciculatum and $A$. mellea, as well as $G$. pustulatum and G. geosporum.

Scutellospora dipurpurescens and S. armeniaca have also ranked first in production of the greatest total spore 
volume in maritime dunes of the Vistula Bar in northwestern Poland (Błaszkowski et al. 2002a). Another large biovolume was by $G$. fasciculatum. In maritime dunes extending from northern New Jersey to Virginia, the species of AMF forming spores of the greatest total spore volume have been Gigaspora gigantea (T.H. Nicolson et Gerd.) Gerd. et Trappe, G. globiferum Koske et C. Walker, G. tortuosum N.C. Schenck et G.S. Sm., S. dipapillosa (C. Walker et Koske) C. Walker et F.E. Sanders, S. fulgida Koske et C. Walker, and S. verrucosa (Koske et C. Walker) C. Walker et F.E. Sanders (Koske 1987).

\section{THE OCCURRENCE OF AMF FOUND IN MARITIME DUNES OF BORNHOLM IN OTHER DUNE SITES OF THE WORLD}

Most of the species of AMF found in dunes of Bornholm were earlier revealed in many other dune sites located in different regions of the world (Table 3). Apart from the Bornholm dunes, in the literature there is no other report of the finding Am. gerdemannii in dune soils. Other species of AMF found in the study presented here, but so far rarely reported from dunes are $G$. walkeri and Pa. laccatum. The former species has originally been described from spores isolated from a pot culture derived from a mixture of the rhizosphere soil and roots of Oenothera drummondii Hook. colonizing maritime dunes adjacent to Tel-Aviv (Błaszkowski et al. 2006). The finding of the fungus in northern Europe suggests it to be adapted to a wide range of temperature. Thus, it may be widely distributed in the world, at least in sand dunes.

Paraglomus laccatum has originally been described (as G. laccatum Błaszk.) from field-collected spores extracted from under Festuca sp. growing in a forest at Jastrzębia Góra in northern Poland (Błaszkowski 1988). The fungus has also relatively frequently been isolated from trap cultures with soils of different cultivated and non-dune uncultivated sites of northern Poland (Błaszkowski et al. 2002a; Tadych and Błaszkowski 2000b; Iwaniuk and Błaszkowski 2004a, b). Dr. C. Walker found it in the United Kingdom (pers. comm.). Thus, this species probably is widely distributed in the world. The infrequent disclosures of Pa. laccatum in field-collected soil samples may result from the lack or irregular sporulation of this fungus in field conditions and a low persistency of its spores. In the field, a great part of AMF either do not sporulate at all or their sporulation is infrequent and seasonal (Stürmer and Bellei 1994; Stutz and Morton 1996). Paraglomus laccatum forms small, hyaline spores with a delicate spore wall that may easily be decomposed by soil microorganisms. Many soil microorganisms are parasites of AMF (Lee and Koske 1994).

Still another interesting AMF found in the study discusses here is G. irregulare, a species recently described from spores coming from under Am. arenaria colonizing sand dunes of Bornholm (Błaszkowski et al. 2008a). Glomus irregulare is probably widely distributed in the world, although rather rarely recorded to date, probably because of the tendency to hide its spores inside roots and the exceptionally rare production of extraradical spores (Błaszkowski et al. 2008a). It has probably earlier many times erroneously been identified as $G$. intraradices based on both spore morphology and results of molecular environmental analyses (Stockinger et al. 2009).

\section{NOTES ON MORPHOLOGY AND DISTRIBUTION OF UNDESCRIBED MORPHOTYPES OF AMF FOUND IN DUNES OF BORNHOLM}

\section{Glomus 130}

The description and illustrations of morphological properties of Glomus 130 spores have been presented by Błaszkowski et al. (2001).

Earlier found associated with Am. arenaria growing in maritime dunes adjacent to Tel-Aviv, Israel (Błaszkowski and Czerniawska 2006; Błaszkowski et al. 2001).

\section{Glomus 149}

Spores single in the soil; hyaline; globose to subglobose; (71-)91(-122) $\mu \mathrm{m}$ diam (Fig. 1). Spore wall with three hyaline layers (layers 1-3; Fig. 2). Layer 1 evanescent, at first smooth, then roughened, (0.5-)1.3(-2.0) $\mu \mathrm{m}$ thick, rarely present in mature spores. Layer 2 laminate, smooth, (2.5-)3.7(-5.5) $\mu \mathrm{m}$ thick. Layer 3 flexible to semi-flexible, (0.8-)1.2(-1.6) $\mu \mathrm{m}$ thick. Layers 1-3 not reacting in Melzer's reagent. Subtending hypha funnel-shaped, (10.0-) $12.3(-16.0) \mu \mathrm{m}$ wide at the spore base, occluded by a curved septum continuous with spore wall layer 3 .

Apart from Glomus 149, only G. achrum Błaszk. et al. and $G$. diaphanum J.B. Morton \& C. Walker form spores remaining hyaline throughout their entire life cycle, whose spore wall is 3-layered and the innermost layer is flexible to semi-flexible.

Compared with Glomus 149 spores, those of G. achrum are much smaller $[(25-) 43(-55) \mu \mathrm{m}$ diam when globose vs. (71-)91(-122) $\mu \mathrm{m}$ diam], their spore wall layers 1 and 3 stain intensively in Melzer's reagent (vs. none of the spore wall layers reacts in this reagent), and have a much narrower subtending hypha $[(2.9-) 4.3(-5.1) \mu \mathrm{m}$ wide at the spore base vs. (10.0-)12.3(-16.0) $\mu \mathrm{m}$ wide at the spore base; Błaszkowski et al. 2009).

The main property separating Glomus 149 and $G$. diaphanum is the reactivity of spore wall layer 1 of the latter species (Błaszkowski 2003; Morton 2002; vs. no reactivity).

\section{Glomus 178}

Spores formed singly in the soil (Fig. 3); sometimes also produced inside spores of other arbuscular fungi. Spores hyaline; globose to subglobose; (35)63(78) $\mu \mathrm{m}$ diam; sometimes egg-shaped; 50-70 × 65-90 $\mu \mathrm{m}$; with one subtending hypha (Fig. 3). Spore wall comprising three hyaline layers (layers 1-3; Fig. 4). Layer 1, forming the spore surface, evanescent, usually slightly roughened on its upper surface, (0.5)0.7(1.0) $\mu \mathrm{m}$ thick, almost always highly deteriorated or completely sloughed in mature spores. Layer 2 laminate, smooth, (2.5)3.5(4.4) $\mu \mathrm{m}$ thick, frequently stratifying into groups of laminae (sublayers) in vigorously crushed spores. Layer 3 flexible, smooth, ca. $0.5 \mu \mathrm{m}$ thick, usually tightly adherent to the lower surface of layer 2 in slightly crushed spores (Fig. 4), but frequently separated from this layer in vigorously crushed spores. None of these layers stains in Melzer's reagent. Subtending hypha hyaline; straight or curved; cylindrical to flared; (3.2)4.6(5.9) $\mu \mathrm{m}$ wide at the spore base.

For the first time found in a pot trap culture with a mixture of the rhizosphere soil and roots of Zea mays L. cultivated near Faro, Portugal, in December 2000. Later isolated from 


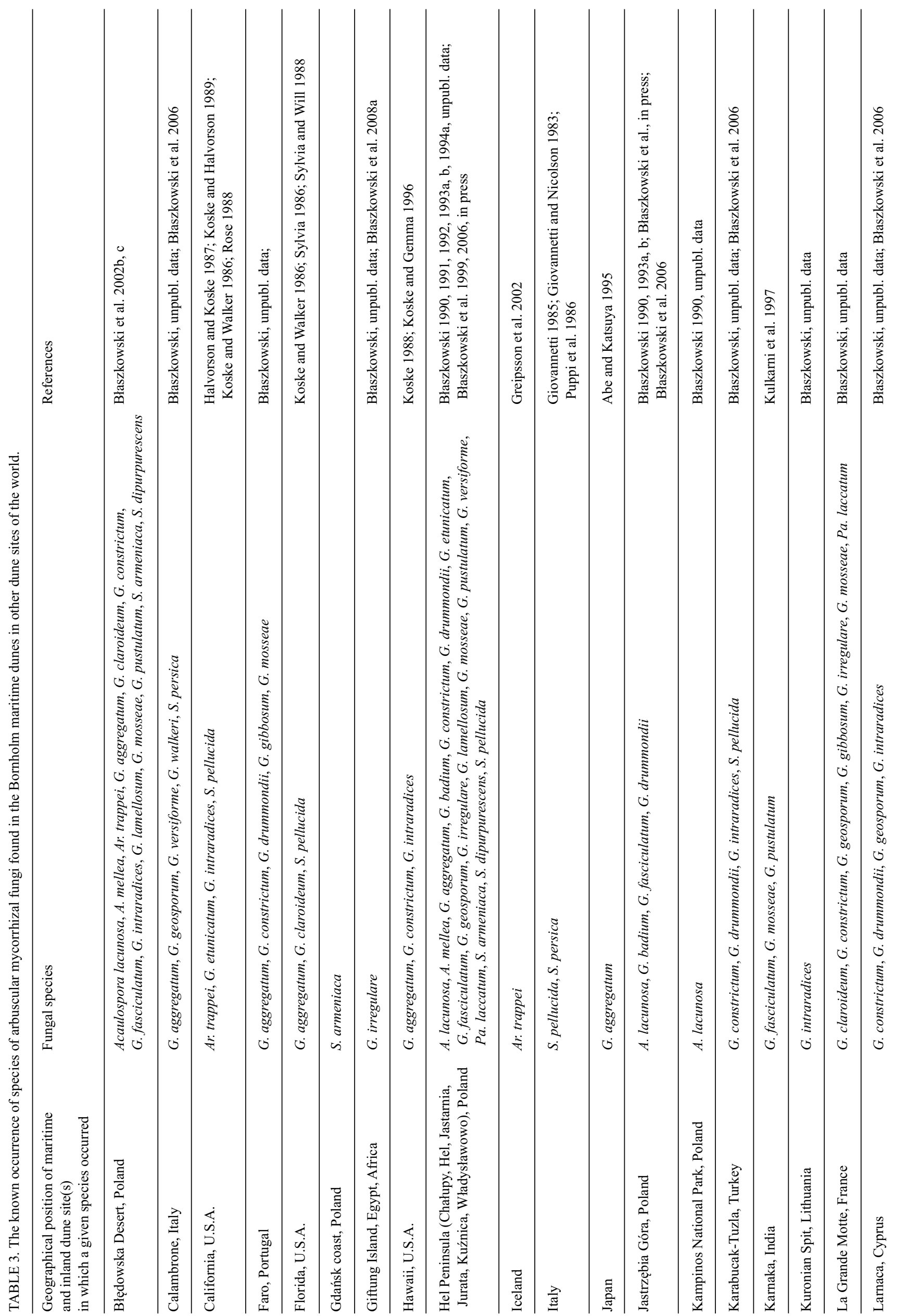




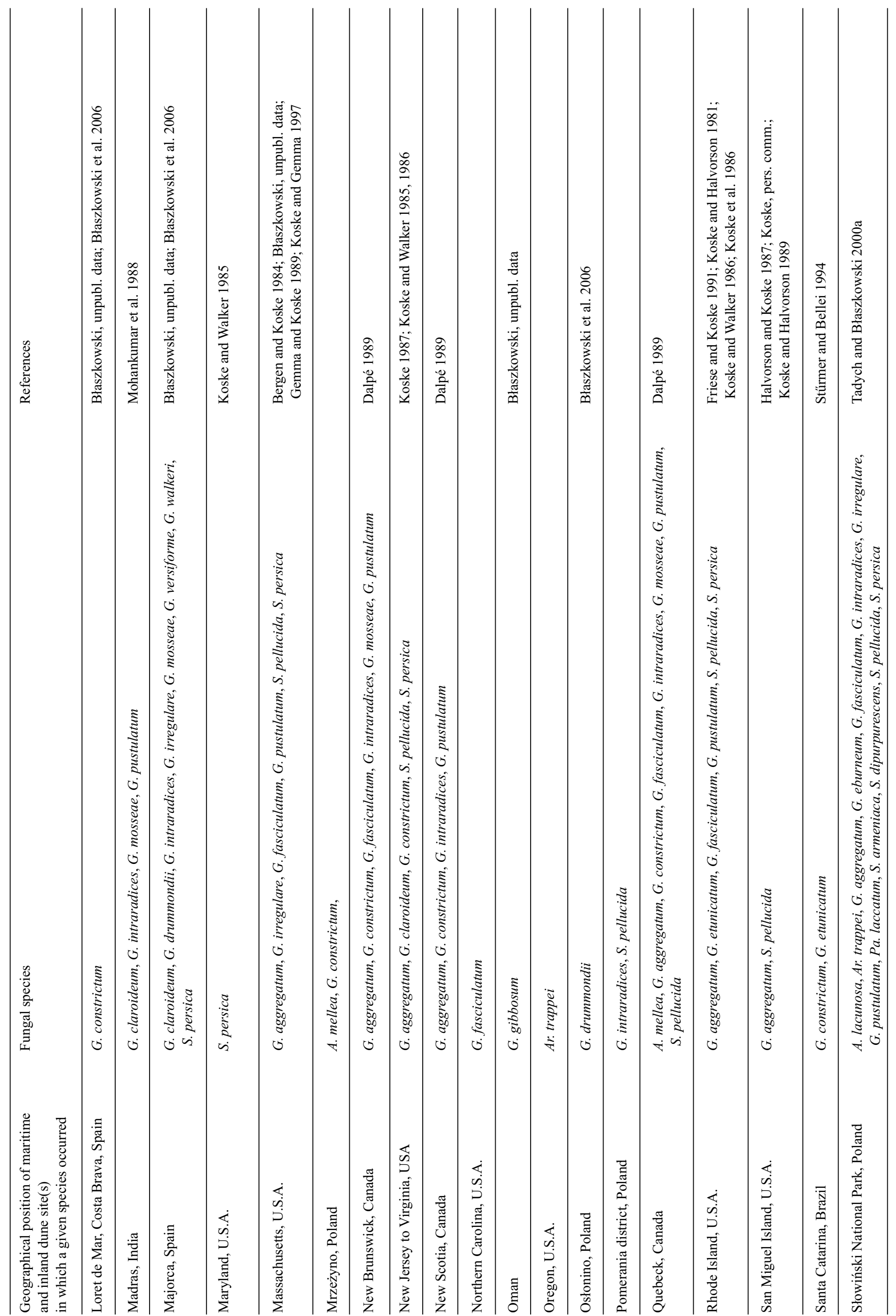


trap cultures containing rhizosphere soils and roots of (1) Am. arenaria growing in mobile dunes of the Mediterranean Sea adjacent to Cape Salinas, Majorca, Spain, in August 2001 (one culture), (2) Am. arenaria colonizing dunes of the Mediterranean Sea near Karabucak-Tuzla, Turkey, in June 2001 (one culture), and (3) Am. arenaria colonizing dunes of the Baltic Sea overlaying Bornholm, in October 2004 (10 cultures).

The distinctive morphological properties of Glomus 178 are its small spores produced singly in the soil and remaining hyaline throughout their entire life cycle, their 3-layered wall structure in which layer 3 is flexible, and the unusually narrow subtending hypha (Figs 3 and 4). Additionally, the unique property of spores of Glomus 178 is that they do not sink in water.

Results of preliminary molecular-phylogenetic analyses of the SSU rDNA sequences of spores of Glomus 178 (data not presented here) indicated it to be most closely related to Paraglomus spp., i.e. $P$. brasilianum, P. laccatum, and P. occultum, fungi also producing glomoid spores. Of them, only the former two species produce only hyaline spores (Błaszkowski 1988; Błaszkowski pers. observ.; Renker et al. 2007). Mature spores of $P$. occultum are slightly yellow (Morton and Redecker 2001).

Although the spore wall of Glomus 178 and $P$. brasilianum consists of three layers, the innermost component of this wall in Glomus 178 is a thin (ca. $0.5 \mu \mathrm{m}$ thick) flexible layer, and in $P$. brasilianum it is a laminate layer, 1.0-2.2 $\mu \mathrm{m}$ thick (Błaszkowski, pers. observ.). Additionally, the upper surface of spore wall layer 2 of $P$. brasilianum is ornamented with minute ridges (Błaszkowski, pers. observ.; Morton and Redecker 2001; Spain and Miranda 1996), whereas all spore wall layers of the fungus discussed here are smooth.

Paraglomus laccatum forms spores with only a 2-layered spore wall (Błaszkowski 1988; Renker et al. 2007), not differentiating layer 3 of the spore wall of Glomus 178. Moreover, the laminate spore wall layer 2 of $P$. laccatum consists of easily separating, thick $(0.5-2.2 \mu \mathrm{m}$ thick) laminae. The laminae of the spore wall layer 2 of Glomus 178 are thin $(<0.5 \mu \mathrm{m}$ thick $)$ and always tightly adhere to each other.

Apart from the differences listed above, the species compared here also differ in size of their spores and subtending hyphae. Spores of Glomus 178 generally are markedly smaller $[(35-) 63(-78)$ $\mu \mathrm{m}$ diam when globose vs. (52-)80-85(-131-140) $\mu \mathrm{m}$ diam in $P$. brasilianum and (50)87(130) $\mu \mathrm{m}$ in $P$. laccatum] and have a narrower subtending hypha $[(3.2-) 4.6(-5.9) \mu \mathrm{m}$ wide at the spore base vs. (4.0-)6.2(-8.3) $\mu \mathrm{m}$ wide in P. brasilianum and (7.4-)9.7(-12.9) $\mu \mathrm{m}$ wide in P. laccatum; Błaszkowski 1988, pers. observ.; Morton and Redecker 2001; Renker et al. 2007].

Another unique property of Glomus 178 is that its spores float in water. Morton and Redecker (2001) reported that Archaeospora trappei spores also tend 
to float in water. Indeed, spores of this fungus sometimes do not sink in water, but only when they are associated with their empty or almost empty sporiferous saccules that then function as a "buoy" (Błaszkowski, pers. observ.).

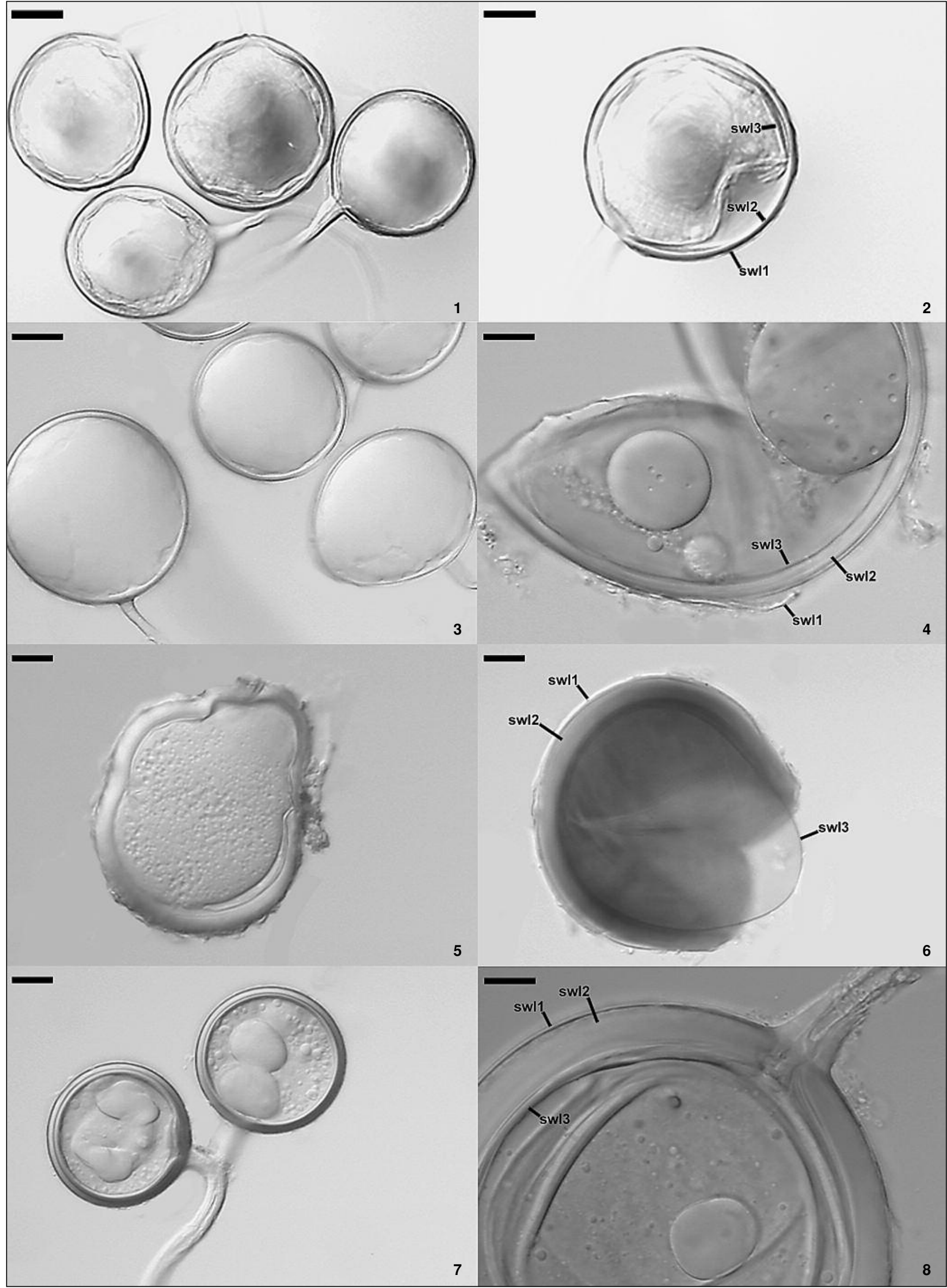




\section{Glomus 194}

Spores formed singly in the soil; pale yellow; globose to subglobose; (52-)62(-68) $\mu \mathrm{m}$ dim; rarely ovoid; 49-69 $\times$ 58-84 $\mu \mathrm{m}$; with one subtending hypha (Fig. 5). Spore wall consists of three layers (layers 1-3; Fig. 6). Layer 1 semipermanent, hyaline, (1.0-)1.7(-2.1) $\mu \mathrm{m}$ thick, usually present as more or less deteriorated structure in mature spores. Layer 2 laminate, pale yellow, (2.3-)4.3(-5.8) $\mu \mathrm{m}$ thick. Layer 3 flexible to semi-flexible, $(0.5-) 0.8(-1.0) \mu \mathrm{m}$ thick. In Melzer's reagent, only spore wall layer 2 stains purplish red (Fig. 6). Subtending hypha cylindrical to funnel-shaped, 2.8-4.0 $\mu \mathrm{m}$ wide at the spore base, occluded by some innermost laminae of spore wall layer 2 and a curved septum continuous with spore wall layer 3

Morphologically, the described species of the Glomeromycota most resembling Glomus 194 are G. drummondii and $G$. walkeri, fungi also producing spores singly in the soil whose spore wall consists of three layers of similar phenotypic properties (Błaszkowski et al. 2006). Moreover, $G$. drummondii spores overlap in size with those of the species discussed here. The main differences separating Glomus 194 from G. drummondii and G. walkeri hide in the biochemical properties of the components of their spore wall. In Glomus 194, spore wall layer 2 stains in Melzer's reagent (Fig. 6). In G. drummondii, the reactive component of its spore wall in this reagent is layer 3, and in $G$. walkeri layer 1. Additionally, even the lower limits of the range of width of the subtending hypha of spores of $G$. drummondii [(4.1-)6.2(-9.3) $\mu \mathrm{m}$ wide at the spore base] and G. walkeri [(7.4-)9.1(-12.7) $\mu \mathrm{m}$ wide at the spore base] exceed the upper limit of that of Glomus 194 spores.

\section{Glomus 202}

Spores formed singly and in loose aggregates in the soil; pale yellow; globose to subglobose; (38-)67(-84) $\mu \mathrm{m}$ diam; with one subtending hypha (Fig. 7). Spore wall with three layers (layers 1-3; Fig. 8). Layer 1 mucilaginous, rather short-lived, hyaline, (0.8-)2.2(-3.5) $\mu \mathrm{m}$ thick. Layer 2 laminate, smooth, pale yellow, (3.3-)4.5(-10.0) $\mu \mathrm{m}$ thick. Layer 3 flexible to semi-flexible, (0.5-)0.8(-1.5) $\mu \mathrm{m}$ thick.
In Melzer's reagent, only spore wall layer 1 stains purplish-red. Subtending hypha straight or slightly recurved; cylindrical to funnel-shaped; (8.0-)11.1(-17.5) $\mu \mathrm{m}$ wide at the spore base; open or occluded by a curved septum continuous with spore wall layer 3 .

Similarly to Glomus 202 spores (Figs 7 and 8), those of $G$. fasciculatum occur in aggregates and singly in the soil, are pale yellow in colour, and their spore wall comprises three layers of which layer 3 is flexible to semi-flexible (Błaszkowski 2003). However, G. fasciculatum spores generally are markedly larger [(50-)105(-130) $\mu \mathrm{m}$ diam when globose vs. (38-)67(-84) $\mu \mathrm{m}$ diam when globose in Glomus 202], their spore wall layer 1 is a permanent structure remaining intact in even older spores (vs. shortlived, frequently highly decomposed or completely sloughed at maturity), and have a subtending hypha of a more regular shape (cylindrical vs. cylindrical to funnel-shaped). Most importantly, in Glomus 202 only spore wall layer 1 stains in Melzer's reagent, whereas in G. fasciculatum the spore wall components reacting in this reagent are layers 1 and 2.

\section{Glomus 206}

Spores formed in loose aggregates, more rarely singly in the soil; pale yellow; globose to subglobose; (45-)70(-90) $\mu \mathrm{m}$ diam; with one subtending hypha (Fig. 9). Spore wall with two layers (layers 1 and 2; Fig. 10). Layer 1 mucilaginous, rather short-lived, hyaline, (0.4-)0.6(-0.8) $\mu \mathrm{m}$ thick. Layer 2 laminate, smooth, pale yellow, (2.1-)3.8(-5.8) thick. In Melzer's reagent, only spore wall layer 1 stains purplish-red (Fig. 10). Subtending hypha straight or slightly recurved; cylindrical to funnel-shaped; (4.0-)7.5(-10.0) $\mu \mathrm{m}$ wide at the spore base; pore open.

Of the known species of the Glomeromycota forming glomoid spores of a 2-layered spore wall in which layer 2 is laminate, Glomus 206 is most closely related in morphology to G. antarcticum, G. aureum, G. deserticola, and $G$. pallidum. Spores of all these fungi form mainly in conglomerates, are yellow-coloured, and more or less overlap in size (Błaszkowski, pers. observ.; Cabello et al. 1994; Hall 1977; Oehl et al. 2003).

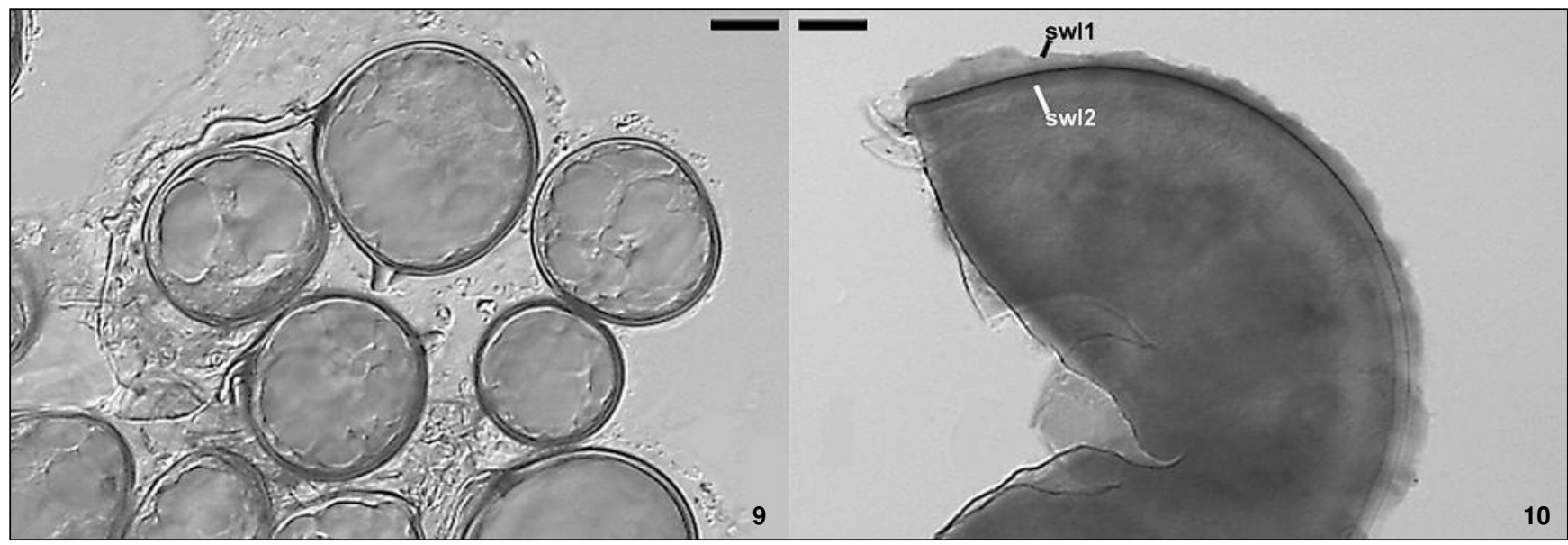

Figs 1 and 2. Glomus 149. 1. Intact spores. 2. Spore wall layers (swl) 1-3. Figs 3 and 4. Glomus 178. 3. Intact spores. 4. Spore wall layers 1-3. Figs 5 and 6. Glomus 194. 5. Intact spore. 6. Spore wall layers 1-3.; note swl 2 stained intensively in Melzer's reagent. Figs 7 and 8. Glomus 202. 7. Spores in a loose aggregate. 8. Spore wall layers 1-3. Figs 9 and 10. Glomus 206. 9. Spores in a loose aggregate. 10. Spore wall layers 1 and 2; layer 1 stained in Melzer's reagent. Figs 1, 2, 8 and 9. Spores in PVLG. Figs 3, 5 and 7. Spores in lactic acid. Figs 4, 6 and 10. Spores in PVLG + Melzer's reagent. Bars: Figs 4-6, 8 and $10=10 \mu \mathrm{m}$; Figs $1-3,7$ and $9=20 \mu \mathrm{m}$. 
The most evident difference readily separating Glomus 206 from most of the species listed above is the reactivity of their spore wall layer 1 in Melzer's reagent. Apart from Glomus 206, spore wall layer 1 of only G. aureum stains in this reagent (Błaszkowski, pers. observ.; Oehl et al. 2003). However, compared with Glomus 206 spores, those of $G$. aureum are produced in sporocarps (vs. in loose aggregates in Glomus 206; Fig. 9), usually are ovoid (vs. globose), and slightly smaller [(27-)40-60 $\mu \mathrm{m}$ diam when globose vs. (45-)70(-90) $\mu \mathrm{m}$ diam when globose].

\section{ACKNOWLEDGMENTS}

This study was partly supported by the Ministry of Science and Higher Education, grant no. 164/NCOST $/ 2008 / 0$.

\section{LITERATURE CITED}

ABE J.-I.P., KATSUYA K. 1995. Vesicular-arbuscular mycorrhizal fungi in coastal dune plant communities. II. Spore formation of Glomus spp. predominates under geographically separated patches of Elymus mollis. Mycoscience 36: 113-116.

ANDERSON R.C., LIBERTA A.E., DICKMAN L.A. 1984. Interaction of vascular plants and vesicular-arbuscular mycorrhizal fungi across a soil moisture-nutrient gradient. Oecologia 64: 111-117.

BERGEN M., KOSKE R.E. 1984. Vesicular-arbuscular mycorrhizal fungi from sand dunes of Cape Cod, Massachusetts. Trans. Brit. Mycol. Soc. 83: 157-158.

BŁASZKOWSKI J. 1988. Three new vesicular-arbuscular mycorrhizal fungi (Endogonaceae) from Poland. Bull. Pol. Ac. Sci. Biol. Sci. 36: 10-12.

BŁASZKOWSKI J. 1990. Polish Endogonaceae. VI. Acaulospora lacunosa. Crypt. Bot. 2: 20-24.

BŁASZKOWSKI J. 1991. Polish Endogonaceae. IX. Glomus aggregatum with spores forming an evanescent outermost wall. Crypt. Bot. 2/3: 130-135.

BŁASZKOWSKI J. 1992. Scutellospora armeniaca, a new species in Glomales (Zygomycetes) from Poland. Mycologia 84: 939-944.

BŁASZKOWSKI J. 1993a. Comparative studies of the occurrence of arbuscular fungi and mycorrhizae (Glomales) in cultivated and uncultivated soils of Poland. Acta Mycol. 28: 93-140.

BŁASZKOWSKI J. 1993b. The occurrence of arbuscular fungi and mycorrhizae (Glomales) in plant communities of maritime dunes and shores of Poland. Bull. Pol. Ac. Sci. Biol. 41: 377-392.

BŁASZKOWSKI J. 1994a. Arbuscular fungi and mycorrhizae (Glomales) of the Hel Peninsula, Poland. Mycorrhiza 5: 71-88.

BŁASZKOWSKI J. 1994b. Polish Glomales 11. Glomus pustulatum. Mycorrhiza 4, 201-207.

BŁASZKOWSKI J. 1995. Glomus corymbiforme, a new species in Glomales from Poland. Mycologia 87: 732-737.

BŁASZKOWSKI J. 1997. Glomus gibbosum, a new species from Poland. Mycologia 89: 339-345.

BŁASZKOWSKI J. 2003. Arbuscular mycorrhizal fungi (Glomeromycota), Endogone and Complexipes species deposited in the Department of Plant Pathology, University of Agriculture in Szczecin, Poland. [online]. Available from www.agro.ar. szczecin.pl/ jblaszkowski/.

BŁASZKOWSKI J., ADAMSKA I., CZERNIAWSKA B. 2002a. Arbuscular mycorrhizal fungi (Glomeromycota) of the Vistula Bar. Acta Mycol. 37: 39-62.

BŁASZKOWSKI J., ADAMSKA I., MADEJ T. 2002b. Glomus lamellosum (Glomales, Zygomycota), an arbuscular mycor- rhizal fungal species new for Poland and Europe. Mycotaxon 81: 281-292.

BŁASZKOWSKI J., ADAMSKA I., CZERNIAWSKA B. 2003. Acaulospora scrobiculata and Glomus versiforme (Glomeromycota), arbuscular fungi newly and second time, respectively, found in Poland. Acta Mycol. 38 (1/2): 31-42.

BŁASZKOWSKI J., CZERNIAWSKA B. 2006. The occurrence of arbuscular mycorrhizal fungi of the phylum Glomeromycota in Israeli soils. Acta Soc. Bot. Pol. 75: 339-350.

BŁASZKOWSKI J., CZERNIAWSKA B., KOWALCZYK S., TURNAU K., ZUBEK S. Ambispora gerdemannii and Glomus badium, two species of arbuscular fungi (Glomeromycota) new for Europe and Poland, respectively. Acta Mycol. (in press).

BŁASZKOWSKI J., CZERNIAWSKA B., WUBET T., SCHÄFER T., BUSCOT F., RENKER C. 2008a. Glomus irregulare, a new arbuscular mycorrhizal fungus in the Glomeromycota. Mycotaxon 106: 247-267.

BŁASZKOWSKI J., CZERNIAWSKA B., ZUBEK SZ., TURNAU K. 2008b. Glomus intraradices and Pacispora robiginia, species of arbuscular mycorrhizal fungi (Glomeromycota) new for Poland. Acta Mycol. 43: 121-132.

BŁASZKOWSKI J., RENKER C., BUSCOT F. 2006. Glomus drummondii and G. walkeri, two new species of arbuscular mycorrhizal fungi (Glomeromycota). Mycol. Res. 110: 555$-566$.

BŁASZKOWSKI J., RYSZKA P., OEHL F., KOEGEL S., WIEMKEN A., KOVÁCS G.M., REDECKER D. 2009. Glomus achrum and G. bistratum, two new species of arbuscular mycorrhizal fungi (Glomeromycota) found in maritime sand dunes. Botany 87: 260-271.

BŁASZKOWSKI J., TADYCH M. 1997. Scutellospora persica (Glomales, Zygomycetes), an arbuscular mycorrhizal fungus new to the mycota of Poland. Mycotaxon 65: 379-390.

BŁASZKOWSKI J., TADYCH M., MADEJ T. 2002c. Arbuscular mycorrhizal fungi (Glomales, Zygomycota) of the Błędowska Desert, Poland. Acta Soc. Bot. Pol. 71: 71-85.

BŁASZKOWSKI J., TADYCH M., MADEJ T., ADAMSKA I., CZERNIAWSKA B., IWANIUK A. 1999. Acaulospora mellea and A. trappei, fungi new to the Mycota of Poland. Acta Mycol. 34: 41-50.

BŁASZKOWSKI J., TADYCH M., MADEJ T., ADAMSKA I., IWANIUK A. 2001. Arbuscular mycorrhizal fungi (Glomales, Zygomycota) of Israeli soils. Mat. II Polsko-Izraelskiej Konf. Nauk. nt. „Gospodarowanie zasobami wodnymi i nawadnianie roślin uprawnych”. Przegląd naukowy Wydz. Inż. Kształt. Środ. 22: 8-27.

CABELLO M., GASPAR L., POLLERO R. 1994. Glomus antarcticum sp. nov., a vesicular-arbuscular mycorrhizal fungus from Argentina. Mycotaxon 60: 123-128.

DALPÉ Y. 1989. Inventaire et repartition de la flore endomycorhizienne de dunes et de rivages maritimes du Quebec, du Nouveau-Brunswick et de la Nouvelle-Ecosse. Naturaliste can. (Rev. Ecol. Syst.) 116: 219-236.

DALPÉ Y., KOSKE R.E., TEWS L.L. 1992. Glomus lamellosum sp. nov.: a new Glomaceae associated with beach grass. Mycotaxon 43: 289-293.

DANIELS B.A., TRAPPE J.M. 1980. Factors affecting spore germination of the vesicular-arbuscular mycorrhizal fungus, Glomus epigaeus. Mycologia 72: 457-471.

D'CUNHA M., SRIDHAR K.R. 2009. Seasonal periodicity of arbuscular mycorrhizal fungi in wild legume Canavalia maritima of the coastal sand dunes. Mycorrhiza News 21: 7$-12$.

FRANKE M., MORTON J.B. 1994. Ontogenetic comparisons of arbuscular mycorrhizal fungi Scutellospora heterogama and Scutellospora pellucida: revision of taxonomic character concepts, species descriptions, and phylogenetic hypotheses. Can. J. Bot. 72: 122-134. 
FRIESE C.F., KOSKE R.E. 1991. The spatial dispersion of spores of vesicular-arbuscular mycorrhizal fungi in a sand dune: microscale patterns associated with the root architecture of American beachgrass. Mycol. Res. 95: 952-957.

GAZEY C., ABBOTT L.K., ROBSON A.D. 1992. The rate of development of mycorrhizas affects the oneset of sporulation and production of external hyphae by two species of Acaulospora. Mycol. Res. 96: 643-650.

GEMMA J.N., KOSKE R.E. 1988. Seasonal variation in spore abundance and dormancy of Gigaspora gigantea and in mycorrhizal inoculum potential of a dune soil. Mycologia 80: 211-216.

GEMMA J.N., KOSKE R.E. 1989. Field inoculation of American beachgrass (Ammophila breviligulata) with V-A mycorrhizal fungi. J. Environm. Manag. 29: 173-182.

GEMMA J.N., KOSKE R.E., CARREIRO M. 1989. Seasonal dynamics of selected species of VA mycorrhizal fungi in a sand dune. Mycol. Res. 92: 317-321.

GERDEMANN J.W., NICOLSON T.H. 1963. Spores of mycorrhizal Endogone species extracted from soil by wet sieving and decanting. Tran. Brit. Mycol. Soc. 46: 235-244.

GERDEMANN J.W., TRAPPE J.M. 1974. The Endogonaceae in the Pacific Northwest. Myc. Memoir 5, 1-76.

GILMORE A.E. 1968. Phycomycetous mycorrhizal organisms collected by open-pot culture methods. Hilgardia 39: 87-105.

GIOVANNETTI M. 1985. Seasonal variations of vesiculararbuscular mycorrhizas and Endogonaceous spores in a maritime sand dunes. Trans. Brit. Mycol. Soc. 84: 679-684.

GIOVANNETTI M., NICOLSON T.H. 1983. Vesicular-arbuscular mycorrhizas in Italian sand dunes. Trans. Brit. Mycol. Soc. 80: 552-557.

GÓRNY M., GRUMA L. 1981. Metody stosowane w zoologii gleby. PWN, Warszawa.

GREIPSSON S., EL-MAYAS H., VESTBERG M., WALKER C. 2002. Arbuscular mycorrhizal fungi in sandy soils in Iceland. Arctic, Antarctic, Alpine Res. 34: 419-427.

GREY W.E. 1991. Influence of temperature on colonization of spring barleys by vesicular-arbuscular mycorrhizal fungi. Plant and Soil 137: 181-190.

HALL I.R. 1977. Species and mycorrhizal infections of New Zealand Endogonaceae. Trans. Brit. Mycol. Soc. 68, 341-356.

HAAS J.H., MENGE J.A. 1990. VA-mycorrhizal fungi and soil characteristics in avocado (Persea americana Mill.) orchard soils. Plant and Soil 127: 207-212.

HALVORSON W.L., KOSKE R.E. 1987. Mycorrhizae associated with an invasion of Erechtites glomerata (Asteraceae) on San Miguel Island, California. Madrono 34: 260-268.

HIJRI I., SÝKOROVA Z., OEHL F., INEICHEN K., MÄDER P., WIEMKEN A., REDECKER D. 2006. Communities of arbuscular mycorrhizal fungi in arable soils are not necessarily low in diversity. Mol. Ecol. 15: 2277-2289.

IWANIUK A., BŁASZKOWSKI J. 2004a. Arbuscular fungi and mycorrhizae of agricultural soils of the Western Pomerania. Part I. Occurrence of arbuscular fungi and mycorrhizae. Acta Mycol. 39(1): 59-84.

IWANIUK A., BŁASZKOWSKI J. 2004b. Arbuscular fungi and mycorrhizae of agricultural soils of the Western Pomerania. Part II. Distribution of arbuscular fungi. Acta Mycol. 39(2): 3-18 .

KHAN A.G. 1974. The occurrence of mycorrhizas in halophytes, hydrophytes and xerophytes, and of Endogone spores in adjacent soils. J. Gen. Microbiol. 81: 7-14.

KOSKE R.E. 1975. Endogone spores in Australian sand dunes. Can. J. Bot. 53: 668-672.

KOSKE R.E. 1981. A preliminary study of interactions between species of vesicular-arbuscular mycorrhizal fungi in a sand dune. Trans. Brit. Mycol. Soc. 76: 411-416.

KOSKE R.E. 1987. Distribution of VA mycorrhizal fungi along a latitudinal temperature gradient. Mycologia 79: 55-68.
KOSKE R.E. 1988. Vesicular-arbuscular mycorrhizae of some Hawaiian dune plants. Pacific Sci. 42: 217-229.

KOSKE R.E., FRIESE C., WALKER C., DALPÉ Y. 1986. Glomus pustulatum: A new species in the Endogonaceae. Mycotaxon 26: 143-149.

KOSKE R.E., GEMMA J.N. 1996. Arbuscular mycorrhizal fungi in Hawaiian sand dunes: Island of Kaua'i. Pacific Sci. 50: 36$-45$.

KOSKE R.E., GEMMA J.N. 1997. Mycorrhizae and succession in plantings of beachgrass in sand dunes. Amer. J. Bot. 84: 118-130.

KOSKE R.E., GEMMA J.N., CORKIDI L, SIGÜENZA C, RINKÓN E. 2004. Arbuscular mycorrhizas in coastal dunes. In: M.I. Martínez, N.P. Psuty (eds), Coastal dunes, ecology and conservation. Ecol. Stud. 171: 173-187.

KOSKE R.E., HALVORSON W.L. 1981. Ecological studies of vesicular-arbuscular mycorrhizae in a barrier sand dune. Can. J. Bot. 59: 1413-1422.

KOSKE R.E., HALVORSON W.L. 1989. Mycorrhizal associations of selected plant species from San Miguel Island, Channel Islands National Park, California. Pacific Sci. 43: 32$-40$.

KOSKE R.E., SUTTON J.C., SHEPPARD B.R. 1975. Ecology of Endogone in Lake Huron sand dunes. Can. J. Bot. 53: 87-93.

KOSKE R.E., TEWS L.L. 1987. Vesicular-arbuscular mycorrhizal fungi of Wisconsin sandy soils. Mycologia 79: 901-905.

KOSKE R.E., WALKER C. 1985. Species of Gigaspora (Endogonaceae) with roughened outer walls. Mycologia 77: 702-720 .

KOSKE R.E., WALKER C. 1986. Species of Scutellospora (Endogonaceae) with smooth-walled spores from maritime sand dunes: two new species and a redescription of the spores of Scutellospora pellucida and Scutellospora calospora. Mycotaxon 27: 219-235.

KULKARNI S., RAVIRAJA N.S., SRIDHAR K.R. 1997. Arbuscular mycorrhizal fungi of tropical dunes of West Coast of India. J. Coastal Res. 13: 931-936.

LAWESSON J.E., SKOV F. 2002. The phytogeography of Denmark revisited. Plant Ecology 158: 113-122.

LEE P.J., KOSKE R.E. 1994. Gigaspora gigantea: parasitism of spores by fungi and actinomycetes. Mycol. Res. 98: 458-466.

MOHANKUMAR V., RAGUPATHY S., NIRMALA C.B., MOHADEVAN A. 1988. Distribution of vesicular-arbuscular mycorrhizae (VAM) in the sandy beach soils of Madras coast. Cur. Sci. 57: 367-368.

MORTON J. B. 2000. Evolution of fungi in Glomales. In: C.W. Bacon, J.F.White (ed.), Microbial endophytes. CRC Press, pp. 121-141.

MORTON J.B. 2002. International Culture Collection of Arbuscular and Vesicular-Arbuscular Mycorrhizal Fungi. West Virginia University: http://www.invam.caf.wvu.edu/.

MORTON J.B., REDECKER D. 2001. Two families of Glomales, Archaeosporaceae and Paraglomaceae, with two new genera Archaeospora and Paraglomus, based on concordant molecular and morphological characters. Mycologia 93: 181-195.

NICOLSON T.H., JOHNSTON C. 1979. Mycorrhiza in Gramineae. III. Glomus fasciculatum as the endophyte of pioneer grasses in maritime sand dunes. Trans. Brit. Mycol. Soc. 72: 261-268.

OEHL F., SIEVERDING E. 2004. Pacispora, a new vesicular arbuscular mycorrhizal fungal genus in the Glomeromycetes. J. Appl. Bot. 78: 72-82.

OEHL F., SIEVERDING E., MADER P., DUBOIS D., INEICHEN K., BOLLER T., WIEMKEN A. 2004. Impact of long-term conventional an organic farming on the diversity of arbuscular mycorrhizal fungi. Oecologia 138: 574-583.

OEHL F., WIEMKEN A., SIEVERDING E. 2003. Glomus aureum, a new sporocarpic arbuscular mycorrhizal fungal species from European grasslands. J. Appl. Bot. 77: 111-115. 
OMAR M.B., BOLLAN L., HEATHER W.A. 1979. A permanent mounting medium for fungi. Bull. Br. Mycol. Soc. 13: 31-32.

OSTROWSKA A., GAWLIŃSKI S., SZCZUBIAŁKA Z. 1991. Metody analizy i oceny właściwości gleb i roślin. Wydaw. IOŚ, Warszawa $334 \mathrm{p}$.

PALENZUELA J., FERROL N., BOLLER T., AZCÓNAQUILAR C., OEHL F. 2008. Otospora bareai, a new fungal species in the Glomeromycetes from a dolomitic shrub-land in the Natural Park of Sierra de Baza (Granada, Spain). Mycologia 100: 282-291.

PORTER W.M., ROBSON A.D., ABBOTT L.K. 1987. Field survey of the distribution of vesicular-arbuscular mycorrhizal fungi in relation to soil pH. J. Appl. Ecol. 24: 659-662.

PUPPI G., RIESS S. 1987. Role and ecology of VA mycorrhizae in sand dunes. Angew. Botanik 61: 115-126.

PUPPI G., CHIAPPERI F., TABACCHINI A., SANVITO A., CARPIGO F. 1986. Endogonaceae del litorale Tirrenico. Micol. Ital. 15, 7-14.

RENKER C., BŁASZKOWSKI J., BUSCOT F. 2007. Paraglomus laccatum comb. nov. - a new member of Paraglomeraceae (Glomeromycota). Nova Hedwigia 84: 395-407.

ROSE S. 1988. Above and belowground community development in a maritime sand dune ecosystem. Plant and Soil 109: 215-226.

SCHENCK N.C., GRAHAM S.O., GREEN N.E. 1975. Temperature and light effects on contamination and spore germination of vesicular-arbuscular mycorrhizal fungi. Mycologia 57: 1189-1194.

SCHÜßLER A., SCHWARZOTT D., WALKER C. 2001. A new fungal phylum, the Glomeromycota: phylogeny and evolution. Mycol. Res. 105: 1413-1421.

SIEVERDING E., OEHL F. 2006. Revision of Entrophospora and description of Kuklospora and Intraspora, two new genera in the arbuscular mycorrhizal Glomeromycetes. J. Appl. Bot. Food Qual. 80: 69-81.

SMITH S.E., READ D.J. 2008. Mycorrhizal symbiosis. 3rd ed. San Diego: Academic Press: 787 p.

SPAIN J.L., DE MIRANDA J.C. 1996. Glomus brasilianum: an ornamented species in the Glomaceae. Mycotaxon 60: 137-142.

SRIDHAR K.R., BEENA K.R. 2001. Arbuscular mycorrhizal research in coastal sand dunes: a review. Proc. Nat. Acad. Sci India 71: 179-205.

STOCKINGER H., WALKER C., SCHÜßLER A. 2009. Glomus intraradices DAOM197198', a model fungus in arbuscular mycorrhiza research, is not Glomus intraradices. New Phytol. 183: 1176-1187.
STUTZ J.C., MORTON J.B. 1996. Successive pot cultures reveal high species richness of arbuscular mycorrhizal fungi in arid ecosystems. Can. J. Bot. 74: 1883-1889.

STÜRMER S.L., BELLEI M.M. 1994. Composition and seasonal variation of spore populations of arbuscular mycorrhizal fungi in dune soils on the island of Santa Catarina, Brazil. Can. J. Bot. 72: 359-363.

STÜRMER S.L., MORTON J.B. 1997. Developmental patterns defining morphological characters in spores of four species in Glomus. Mycologia 89: 72-81.

SYLVIA D.M. 1986. Spatial and temporal distribution of vesicular-arbuscular mycorrhizal fungi associated with Uniola paniculata in Florida foredunes. Mycologia 78: 728-734.

SYLVIA D.M., WILL M.E. 1988. Establishment of vesiculararbuscular mycorrhizal fungi and other microorganisms on a beach replenishment site in Florida. Appl. Environm. Microbiol. 54: 348-352.

TADYCH M., BŁASZKOWSKI J. 2000a. Arbuscular fungi and mycorrhizae (Glomales) of the Słowiński National Park, Poland. Mycotaxon 74: 463-483.

TADYCH M., BŁASZKOWSKI J. 2000b. Arbuscular mycorrhizal fungi of the Brda river valley in the Tuchola Forests. Acta Mycol. 35: 3-23.

WALKER C. 1983. Taxonomic concepts in the Endogonaceae: spore wall characteristics in species descriptions. Mycotaxon 18: 443-455.

WALKER C. 2008. Ambispora and Ambisporaceae resurrected. Mycol. Res. 112: 297-298.

WALKER C., SCHÜßLER A. 2004. Nomenclatural clarifications and new taxa in the Glomeromycota. Mycol. Res. 108: 979$-982$

WALKER C., TRAPPE J.M. 1993. Names and epithets in the Glomales and Endogonales. Mycol. Res. 7: 339-344.

WALKER C., VESTBERG M. 1994. A simple and inexpensive method for producing and maintaining closed pot cultures of arbuscular mycorrhizal fungi. Agric. Sci. Finl. 3: 233-240.

WALKER C., VESTBERG M., DEMIRCIK F., STOCKINGER H., SAITO M., SAWAKI H., NISHMURA I., SCHÜßLER A. 2007a. Molecular phylogeny and new taxa in the Archaeosporales (Glomeromycota): Ambispora fennica gen. sp. nov., Ambisporaceae fam. nov., and emendation of Archaeospora and Archaeosporaceae. Mycol. Res. 111: 137-153.

WALKER C., VESTBERG M., SCHÜßLER A. 2007b. Nomenclatural clarifications in Glomeromycota. Mycol. Res. 111: 253-255. 